nych, ich logicznego przepracowywania, uzasadniania i obrony. Zasadnicza zmiana nastąpiła z chwilą zakorzenienia się Kościoła w świecie, co przypada już na okres wczesnej patrystyki. ${ }^{57}$

Lublin

Ks. STANISEAW WITEK

Ks. Edward Zawiszewski, Pelplin

\title{
ZAGADNIENIA SPOLECZNE W PRAWODAWSTWIE STAREGO TESTAMENTU
}

Na kartach Pisma św. Starego Testamentu znajdujemy cały szereg przepisów prawnych odnoszących się do różnych przejawów życia społecznego. Tworzą one pewnego rodzaju kodeks społeczny, mający regulować życie spoleczeństwa izraelskiego. W odróżnieniu jednak od kodeksów społecznych dzisiejszej doby nosi on na sobie szczególne piẹtno pochodzenia od Boga w sposób bezpośredni.

Uwzględnienie powyższego faktu pozwala należycie ocenić zasadnicze tendencje przejawiające się w ustawodastwie społecznym narodu wybranego, a szczególnie podstawową zasadę równości wszystkich członków społeczeńswa ${ }^{1}$.

1. Zasada równości członków społeczeństwa może być słusznie uznana za fundament izraelskiego kodeksu społecznego. Pragnąc bowiem zapewnić swemu społeczeństwu pomyślne warunki rozwoju prawodawca izraelski oparł je na zdrowych zasadach równowagi społecznej. Społeczeństwo więc Izraela składać się miało z ludzi równouprawnionych, związanych ze sobą ścisłymi więzami wspólnoty ${ }^{2}$. Współobywatel, współczłonek społeczeństwa określany bywa

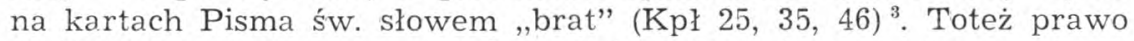
mojżeszowe nie zna uprzywilejowania jakiegoś stanu czy warstwy społecznej ${ }^{4}$. Jednakową opieka otacza wszystkich członków społeczeństwa. Wymowną ilustracją powyższej zasady jest nakaz, skierowany do sędziów, polecający im trzymać się skrupulatnie zasad sprawiedliwości bez względu na osobę podsądnego ${ }^{5}$. Jak wielkie zaś

57 Ibid., kol. $751-752$.

1 Zob. Fr. E. K ü ber, Die soziale und volkswirtschaftliche Gesetzgebung des A.T., Wiesbaden 1870, 24. - por. R. P e ters, Die soziale Fürsorge im A.T., Paderborn, 1936; M. Buber, Biblischer Humanismus ${ }^{3}$, Werke 2 (München 1964) 1085-92. $11-12$.

2 Zob. Fr. B u h l, Die sozialen Verhältnisse der Israeliten, Berlin 1899,

3 Zob. R. Peters, dz. cyt. 7.

4 Por. Fr. K übe l, dz. cyt. 24 . 
znaczenie przywiązywał pracodawca do zachowania sprawiedliwości świadczy znamienny nakaz z Księgi Wyjścia $(23,3)$ : A także $w$ procesie nie czyń względów dla biednych ${ }^{6}$. Nakaz ten jest tym bardziej znamienny, że przecież człowiek biedny cieszy się specjalnymi względami prawodawcy izraelskiego. Biednym bowiem zapewnia on szczególną opiekę prawa, zapewniając im obronę wobec przemożnej potęgi bogaczy. Tymczasem w sytuacji, w której wchodzi w grę obrona sprawiedliwości, odstępuje od tej zasady i stawia sprawiedliwość ponad współczucie dla biednych. W ten sposób niedwuznacznie daje do zrozumienia, że żaden motyw nie może uprawniać do zbaczania $\mathrm{z}$ drogi sprawiedliwości. Nawet motywy najbardziej szlachetne, jak litość nad nieszczęściem ludzkim, muszą ustąpić przed postulatem sprawiedliwości. Co zaś prawodawca określił tak silnie i stanowczo jako normę i postulat, to nieustannie podejmować będą Prorocy w formie żądania i groźby. W swej mowie wstępnej, w której piętnuje występki Izraela, Izajasz woła: Troszcie się o sprawiedliwość, a jako jedno $\mathrm{z}$ największych dóbr po nawróceniu obiecuje: Przywrócę twoich sędziów, jak dawniej. Syjonowi zaś zapowiada: Wówczas cię nazwą: Miastem Sprawiedliwości (Iz 1, 17. 26.).

Sąd bezstronny i całkowicie niezawisły jest idealem prawodawcy, gdyż każdy obywatel ma równe prawo do uzyskania sprawiedliwego wyroku. Każdy ma te same uprawnienia obywatelskie. Wykluczenie bowiem uprzywilejowania jakiegoś stanu czy warstwy społecznej zabezpiecza równouprawnienie wszystkich członków społeczeństwa. Podstawą zaś równouprawnienia jest równość wszystkich wobec Boga - Jahwe. Moment powyższy został wyraźnie podkreślony w przepisach normujących obowiązek składania dorocznego podatku na rzecz świątyni. Według bowiem przepisów, zawartych w Księdze Wyjścia, każdy Izraelita winien był składać jednakową sumę pieniędzy: pół sykla ${ }^{7}$. Przy czym zastrzega wyraźnie, że Bogaty nie będzie zwiększał, a ubogi nie będzie zmniejszat wagi pót sykla ${ }^{8}$, aby pouczyć, że wobec Boga nie ma żadnej różnicy między nimi. Bogaty nie ma żadnych przywilejów, ani też większych uprawnień aniżeli ubogi, a ubogi nie potrzebuje czuć się mniej wartościowym niż jego bogaty współobywatel.

2. Zresztą speieczeństwo izraelskie miało być społeczeństwem bezklasowym, w którym byłaby zachowana ró w nowag a w podziale dóbr materialnych. Okazja do zrealizowania tego założenia stał się podział ziemi obiecanej, kiedy to każdy Izraelita otrzymał uprawnienie do uczestniczenia w podziale ziemi, przepro-

5 Zob. Pwt 16, 18-20; Wj 23, 1-3. 6-8.

6 Zob. Ks. St. E a c h, Księga Wyjścia, Poznań 1964, 226. - Biblia Tyniecka poprawia T M i czyta: „dla bogatych” (zob. Pismo św.; Poznań $1965,95)$.

7 Wj $30,11-16$. - por. Fr. K ü be l, dz. cyt. 21.

8 Wj 30, 15. - zob. Ks. St. E a c h, dz. cyt. 268. 
wadzonym drogą losowania. Podzielono w ten sposób całą Palestynę na poszczególne pokolenia, rody i rodziny, uznając jednakowe prawa wszystkich obywateli. Żadnej roli nie odgrywało przy tym ani stanowisko, ani pochodzenie społeczne, a uwzględniano jedynie liczbę członków danego rodu lub rodziny ${ }^{9}$.

W ten sposób każdy obywatel otrzymał wówczas prawo do odpowiedniej działki ziemi, która miała mu dostarczać środków utrzymania. Zyskiwał dzięki temu niezależność pod względem gospodarczym oraz został związany silnymi więzami z całą społecznością narodu wybranego. Wylosowany dział ziemi miał pozostawać w danej rodzinie we wieczystym jej posiadaniu. W dążeniu bowiem, które miało ustrzec naród wybrany przed szkodliwym w skutkach podziałem na klasy uprzywilejowane gospodarczo i klasy pozbawione dóbr materialnych, prawodawca starał się przeciwstawić nadmiernemu bogaceniu się jednostek i tworzeniu przez nich wielkich majątków przez wykupowanie ziemi rodowej z rąk jej pierwotnych właścicieli. Ziemia nie mogła stać się przedmiotem spekulacji handlowych i w zasadzie nie mogła ulec przewłaszczeniu.

Żaden bowiem Izraelita nie miał absolutnie prawa do ziemi. Otrzymał ją losem z nadania Bożego i był tylko jej użytkownikiem, a właścicielem ziemi pozostawał nadal Bóg sam ${ }^{10}$. Wszelkie zaś transakcje kupna i sprzedaży miały za przedmiot nie samą posiadłość ziemską, lecz jedynie otrzymywane $\mathrm{z}$ niej produkty ${ }^{11}$. Właściciel sprzedający ziemię nigdy nie tracił swoich uprawnień i w każdym czasie mógł wykupić sprzedaną posiadłość, czy to sam osobiście czy też za pośrednictwem swoich krewnych ${ }^{12}$. Krewni zaś byli obciążeni obowiązkiem wykupu sprzedanej ziemi na tej samej zasadzie solidarności rodowej, która w wypadku zabójstwa obowiązywała ich do krwawego pomszczenia krewniaka. Poza tym prawo wykupu ziemi rodowej nie ulegało przedawnieniu. Jeśli zaś zdarzyło się, że ani sam właściciel, ani jego krewni nie mogli wykupić sprzedanej ziemi, to i w tym wypadku właściciel nie tracil praw swoich do ziemi rodowej. Odzyskiwał bowiem własność swoją w najbliższym roku jubileuszowym. W roku jubileuszowym bowiem ziemia sprzedana lub oddana $\mathrm{w}$ zastaw miała wracać do swego właściciela ${ }^{13}$. Znamienne przy tym jest to, że do właściciela musiała wrócić także ziemia ofiarowana na rzecz świątyni ${ }^{14}$.

Czy rzeczywiście ziemia rodowa utrzymywała się $\mathrm{w}$ posiadaniu

9 Zob. Lb 26, 54; 33, 54.

10 Zob. Kpł 25, 23; Lb 33, 53.

11 Zob. $\mathrm{Kpl} 25,16$.

12 Zob. Kpł 25, 23-27. - Por. R. de $\mathrm{Vaux}$, Les Institutions de l'Ancien Testament, I, Paris 1958, 40.

13 Zob. Kpł 25, 10. 28. - por. R. North, Sociology of the Biblical Jubilee, Roma 1954, 158-175.

14 Zob. Kpł 27, 16-21. 
danych rodów? $\mathrm{Na}$ to pytanie dostarczają nam odpowiedzi częściowo księgi historyczne i prorockie.

W trzeciej Księdze Królewskiej znajdujemy opis incydentu, związanego $\mathrm{z}$ winnicą Nabota ${ }^{15}$. Nabot pada tu ofiarą bezprawia i gwałtu za to, że nie chciał sprzedać królowi ziemi rodowej, „dziedzictwa ojców swoich". Z powyższego incydentu możemy wnioskować o tym, że przekonanie o nieprzewłaszczalności ziemi rodowej i zakaz sprzedawania ziemi zapadł głęboko w świadomość poszczególnych obywateli. Mimo to jednostki wpływowe i bardziej bezwzględne nie liczyły się z prawem, gromadząc majątki ze szkodą współobywateli. Zły przykład lekceważenia prawa dawali niestety sami królowie, którzy mieli być stróżami sprawiedliwości w narodzie wybranym. W takiej sytuacji obrońcami ludu i rzecznikami sprawiedliwości stawali się jedynie mężowie, Boży, prorocy. W wypadku Nabota przeciwstawił się samowoli króla Achaba prorok Eliasz, a klasycznym przykładem interwencji proroka wobec chciwości bogaczy pozostaje Izajaszowe „biada”: „Biada tym, którzy przydają dom do domu, przyłączają rolę do roli, tak iż nie ma wolnego miejsca, i wy sami mieszkacie w środku kraju" (Iz 5, 8).

Nawiązując do ideału Prawodawcy w Pięcioksięgu Mojżeszowym, Izajasz piętnuje nienasyconą żądzę posiadania i wykazuje, że gromadzenie przez bogaczy ziemi rodowej jest szkodliwe dla społeczeństwa. Wykupywanie ziemi z rąk jej właściwych posiadaczy prowadzi do osłabienia narodu. Zubożałe masy nędzarzy, wyzute $\mathrm{z}$ posiadania własnej posiadłości rodowej, przestaja być pełnoprawnymi obywatelami. Przestają być ,joszew ha'ir”, a stają się tylko „joszew ba ir" czyli mieszkańcami obojętnymi na losy narodu, z którym czują się mało związani. Społecznego znaczenia Mojżeszowego prawa o nieprzewłaszczalności ziemi rodowej dowodzi więc Izajasz najpierw racjami rozumowymi, gdyż zwraca się do ludzi, którzy nic sobie nie robią z Boga i Jego praw. W dalszych jednak wierszach cdwołuje się do autorytetu Boga, zapowiadając nieurodzaj i zniszczenie kraju, jako karę, przez którą Pan Bóg w odpowiedni sposób będzie karać chciwość bogaczy.

3. Zasada nieprzewłaszczalności ziemi rodowej znalazła swój oddźwięk także w prawie spadkowym I zraelitów, gdzie postanowienia, odnoszące się do prawa dziedziczenia, ograniczały poważnie uprawnienia testatora do rozporządzenia swoim mieniem, wyznaczając $\mathrm{z}$ góry osobę spadkobiercy ${ }^{16}$. Z mocy prawa, w normalnych warunkach, prawo dziedziczenia przysługiwało jedynie synom. Przy czym pierworodny otrzymywał podwójną część spadku ${ }^{17}$. Jeżeli

15 Zob. $3 \mathrm{Krl} \mathrm{21,} \mathrm{1-16.}$

16 Por. R. de Vaux, dz. cyt. $89-91$; A. G. Barrois, Manuel d'Archeologie Biblique, II, Paris 1953, 28-31; M. Cohn, Erbrecht, Jüdisches Lexicon II, 442.

17 Por. Pwt 21, 15-17. 
zaś dany obywatel nie miał syna, wówczas prawo dziedziczenia przechodziło na córki, z tym jednak zastrzeżeniem, że córki, dziedziczące majątek rodowy, zobowiąane były do zawierania związków małżeńskich wyłącznie w obrębie własnego pokolenia ${ }^{18}$. Dzięki temu ziemia rodowa pozostawała w posiadaniu danego pokolenia i stan jego posiadania nie ulegał uszczupleniu, a równowaga gospodarcza społeczeństwa nie doznawała zachwiania.

Innym sposobem prawnego wyznaczenia spadkobiercy był określcny ustawowo o bowią ze k lewir a tu, który był równocześnie jednym ze sposobów zabezpieczenia bytu materialnego opuszczonej wdowy ${ }^{19}$. Z ustanowienia Prawodawcy pierworodny syn, urodzony z małżeństwa lewirackiego, był uznawany prawnie za potomka zmarłego pierwszego męża swojej matki i przejmował na siebie wszelkie prawa swego legalnego ojca, zwłaszcza zaś jego imię i prawo do posiadłości rodowej po zmarłym ${ }^{20}$.

4. W aspekcie troski Prawodawcy o sprawiedliwy podział dóbr materialnych wśród społeczeństwa izraelskiego należy patrzeć także na postanowienia, regulujące zagadnienie wierzytelności i dług ów. Według intencji Prawodawcy bowiem udzielenie pożyczki miało być aktem miłości bliźniego, a nie spekulacją dochodową. Wychodził on z założenia, że najczęstsza przyczyna zaciagania pożyczki bylo to, co określamy jako ,extrema necessitas”. Wykorzystanie zaś nieszczęścia bliźniego dla własnej korzyści. byłoby niesprawiedliwością. Dlatego Prawodawca potraktował pożyczkę jako jeden ze sposobów normalnej pomocy sąsiedzkiej dla sprawnego i właśc:wego funkcjonowania gospodarstwa. Starał się on osiagnąc to przez nadanie pożyczce chrakteru obowiązku religijnego ${ }^{21}$ oraz przez stanowczy zakaz pobierania procentów od współobywateli ${ }^{22}$.

Wierzyciel, udzielając pożyczki, był uprawniony przyjąć w zastaw jakieś przedmioty na rzecz udzielonej pożyczki. Niekłamanym wszakże podziwem musi nas przejąc tak wysoce humanitarne zarządzenie, na mocy którego nie wolno było komornikowi wchodzić do domu dłużnika, aby tam wybrać przedmiot do zajęcia w zastaw ${ }^{23}$ - jedynie sam dłużnik miał prawo wybrać odpowiednie przedmioty i wynieść je na dwór do czekającego tam wierzyciela. Pod żadnym zaś pretekstem nie było dozwolone zajmować w zastaw przedmiotów, niezbędnie potrzebnych do codziennego życia. Zatem nie było wolno zajmować kamieni młyńskich, czyli żaren ${ }^{24}$, których używano codziennie do zmielenia mąki na chleb, ani odzienia wdowy ${ }^{25}$. Jeżeli zaś

18 Por. Lb 27, 8; 36, 1-12.

19 Zob. R. P e ter s, dz. cyt. 54.

20 Pwt 25, 5-6. por. Fr. Nötscher, Biblische Altertumskunde, Bonn 1940, 87.

21 Pwt 15, 8. - por. R. de $\mathrm{V} \mathrm{a} \mathrm{u} \mathrm{x,} \mathrm{dz.} \mathrm{cyt.} \mathrm{I,} 260$.

22 Zob. Wj 22, 24; Kpł 25, 35-38; Pwt 23, 20. - por. Ks. S. E a c h, dz. cyt. 224; R. de Va ux, dz. cyt. I, 261. A. B a r ro is, dz. cyt. II 217-221. 
dłużnik nie miał nic innego do zastawienia, jak tylko swoje wierzchnie odzienie, to wówczas wierzyciel musiał je oddawać przed zachodem słońca, aby ubogi mógł okryć się nim na noc ${ }^{26}$.

Prawdziwym zaś ukoronowaniem tych postanowień prawnych mających regulować udzielanie pożyczki i kwestię długów, była in stytucja roku szabatowego. W roku szabatowym bowiem wygasały wszelkie wierzytelności i długi. W ten sposób Prawodawca pomagał ubogim do zrzucenia wszelkich ciężarów, obciążających ich hipotekę, i bronił ich przed popadnięciem w ostateczną nędzę.

Pomimo to zdarzało się, że jakiś obywatel popadał $\mathrm{w}$ tak straszną nędzę, że nie mając środków do życia zaprzedawał się $w$ niewolę. Nigdy jednak nie mogła to być niewola wieczysta. W roku szabatowym niewolnicy pochodzenia izraelskiego musieli być wyzwoleni, a właściciel był obowiązany zaopatrzyć ich we wszystko, co było konieczne do podjęcia samodzielnej egzystencji, aby nie byli zmuszeni na nowo zaprzedać się $\mathrm{w}$ niewolę $\mathrm{z}$ braku środków do życia ${ }^{27}$.

W ogóle położenie niewolników, nawet cudzoziemców, było w Izraelu o wiele znośniejsze aniżeli w najbardziej cywilizowanych krajach ówczesnych. Czymś niespotykanym w świecie starożytnym było już to, że prawodawca w ogóle zajmował się ulżeniem ich doli i przyznawał im osobowość prawną. A prawo izraelskie szło jeszcze dalej, biorąc w obronę niewolnika nawet przed jego właścicielem. Za okaleczenie niewolnika, powodujące trwałe uszkodzenie jakiegoś organu ciała np. złamanie ręki, czy nawet wybicie zęba, właściciel tracił władzę nad niewolnikiem i musiał przywrócić mu wolność ${ }^{28}$. Tym mniej nie miał on prawa pozbawić niewolnika życia, jak to było np. u Rzymian. Za zabójstwo niewolnika pan jego był pociągany do odpowiedzialności. Poza tym niewolnikom przysługiwało prawo do odpoczynku w dzień szabatu oraz w inne dni świąteczne ${ }^{29}$.

Te postanowienia prawne łagodziły w poważnej mierze dolę niewoników, i dzięki nim sytuacja niewolników izraelskich była bardziej zbliżona do położenia robotników najemnych, jedynie z tą różnicą, że robotnik utrzymywał wynagrodzenie za pracę, a niewolnik nie pobierał zapłaty.

5. W sprawie $\mathrm{zap} \nmid \mathrm{aty} \mathrm{za}$ prace $\mathrm{najemna}$ prawodawca zabiera głos przede wszystkim w tym celu, aby nakazać wypłacanie zapłaty zaraz po wykonaniu roboty: Tegoż dnia oddasz mu zapłate, nie pozwolisz zajść nad nia słońcu, gdyż jest on biedny i całym ser-

Zob. Pwt 24, 10-11. - por. A. B arrois, dz. cyt. 219.

Zob. Pwt 24, 6.

Zob. Pwt 24, 17.

Zob. Pwt 24, 12-13; Wj 22, 25.

Zob. Pwt 15, 12-15. - por. Fr. N öt s c her, dz. cyt. 141.

Zob. Wj 21, 26-27. - por. Ks. $€$ a c h, dz. cyt. 213.

Zob. Pwt 12, 12; 16, 11. 
cem jej pragnie, by nie wzywat Jahwe przeciw tobie, a to by cie obciążyło grzechem (Pwt 24, 15) ${ }^{30}$.

6. Jest rzeczą oczywistą, że pomimo całej troski o zachowanie równowagi gospodarczej $\mathrm{w}$ społeczeństwie izraelskim prawodawca nie był w stanie przeprowadzić swoich zamierzeń w sposób idealny, ani też uniknąć wszelkiego zróżnicowania społecznego. Także Mojżesz uznaje to, kiedy oświadcza ludowi: Ubogiego bowiem nie zabraknie w tym kraju (Pwt 15, 11) ${ }^{31}$. Los ubogich w Izraelu był jednak z pewnością znacznie znośniejszy, aniżeli w innych krajach. Przede wszystkim oszczędził im Prawodawca wielu upokorzeń przez podkreślenie ich równości społecznej z bogatymi, jak to wykazał przepis o składaniu podątku na świątynię.

Stary Testament patrzy na ubóstwo jako na zło i nie zna pojęcia ubóstwa w znaczeniu ofiary i wyrzeczenia się $\mathrm{z}$ motywów religijnych. W tym ujęciu ujawnia się jednak prawda, że ubóstwo nie jest przeznaczone człowiekowi przez Boga. Raczej przeciwnie, ideałem jest dobrobyt całego społeczeństwa i całkowite wyeliminowanie nędzy. Dlatego też czasy mesjańskie będą przez proroków przedstawiane, jako czasy rajskiej pomyślności i dobrobytu.

Niemniej jednak Prawodawca izraelski jest trzeźwym realistą i zdaje sobie sprawę $z$ tego, że ideał powszechnego dobrobytu nie będzie osiągnięty. Nie pomija więc milczeniem zagadnienia nędzy i ubóstwa, ani też nie pozostawia go dobrej woli jednostek, ale stara się ustawowo uregulować problem opieki nad nieszczęśliwymi i potrzebującymi. Według słów autora biblijnego opiekunem ubogich i nieszczęśliwych jest sam Bóg - Jahwe (Pwt 10, 18). I nie było to powiedzenie gołosłowne, gdyż $\mathrm{w}$ oparciu o autorytet Jahwe podaje on nakazy, mające na celu zapewnienie ubogim minimum środków, koniecznych do utrzymania życia.

Przede wszystkim Prawodawca obciąża obowiązkiem opieki nad ubogimi posiadaczy ziemi, gdyż w ujęciu Prawodawcy izraelskiego prawo do ziemi nie miało charakteru absolutnego. Właścicielem ziemi był w rzeczywistości sam Bóg, który Izraelitom dał Ziemię Obiecaną w użytkowanie ${ }^{32}$.

W przeciwieństwie do prawa rzymskiego Mojżeszowe prawo własności pociągało za sobą poważne konsekwencje społeczne, kładąc tamę poczynaniom szkodliwym dla Społeczeństwa. Użytkowanie własności w rozumieniu prawa Mojżeszowego zostało potraktowane jako służba dla dobra całej społeczności, a nie jako środek do zaspokojenia jedynie indywidualnych potrzeb czy zachcianek. $\mathrm{Na}$ tej podstawie prawo własności zostało ograniczone przez nałożenie na

30 Por. Kpł 19, 13; Tob. 4, 14; Jr 22, 13.

31 Por. Mt 26, 11.

32 Zob. Kpł 25, 23; Lb 33, 53.

Ruch Biblijny i Liturgiczny - 111 
właściciela obowiązków na rzecz społeczefistwa, zwłaszcza świątyni i ubogich.

Na rzecz ubogich Prawodawca wyznaczył specjalną dziesięcinę co trzy lata (Pwt 14, 28). Ponadto ubogim i potrzebującym należało się to, co samo urosło na polu w roku szabatowym i w roku jubileuszowym (Wj 23, 11) ${ }^{33}$. Należał im się także ostatek zboża i owoców na polu i w ogrodzie oraz kłosy i owoce opadające na ziemię ${ }^{34}$. Poza tym każdy ubogi miał prawo zaspokoić swój głód, zrywając kłosy na polu i winogrona w winnicy, przez którą przechodził, z tym jedynie zastrzeżeniem, aby nic nie wynosił z sobą, a kłosów nie żął sierpem, ale jedynie zrywał ręką ${ }^{35}$.

Spośród ubogich i potrzebujących szczególną troskliwością otoczył Prawodawca wdowy i sieroty, jako najbardziej potrzebujące opieki i pomocy. Za ich krzywdami Bóg się będzie ujmować w szczególny sposób ${ }^{36}$.

Toteż krzywdy, wyrządzane sierotom i wdowom, są najbardziej napiętnowane, a pomoc dla nich zalicza się do czynów najbardziej zasługujących. Wspaniała ilustracją takiego rozumienia prawa Mojżeszowego jest słynne wyznanie sprawiedliwego Joba, który za szczególna podstawę do chluby wobec Boga poczytuje sobie miłosierdzie wobec wdów, sierót i biednych ${ }^{37}$.

Reasumując dokonany przegląd kodeksu społecznego Izraela, możemy śmiało st́wierdzić, że takie prawo mogło narodowi wybranemu zapewnić pomyślne warunki rozwoju. Całkowicie jest więc uzasadniona duma, $\mathrm{z}$ jaką autor Pięcioksięgu podkreśla wartość tego prawa: Któryż naród wielki ma prawa i nakazy tak sprawiedliwe, jak całe to Prawo, które ja wam dziś nadaję (Pwt 4, 8).

Wreszcie musimy przyznać, że te idee i prawa, tak pełne humanitaryzmu, nie sa dalekie od ducha Nowego Testamentu i łatwo możemy rozpoznać $w$ nich fundamenty i postawy, na których Boski Zbawiciel nasz rozwinął, udoskonalił i dopełnił naukę Bożą Nowego Zakonu. Albowiem jak jeden jest Autor ksiąg świętych, który mówił: do ojców przez proroków, na końcu zaś tych dni przemówił do nas przez Syna" (Hbr 1, 1--2), tak jedno jest Objawienie, stanowiące jedną całość w księgach Starego i Nowego Przymierza.

Pelplin KS. EDWARD ZAWISZEWSKI

33 Por. Kpl 25, 6. - zob. Ks. S. E a c h, dz. cyt. 228.

34 Zob. Kpł 23, 22; Pwt 24, 19-22.

35 Zob. Pwt 23, 25-26.

36 „Nie będziesz krzywdził żadnej wdowy i sieroty. Jeślibyś ich skrzywdził i będą się skarżyli do mnie, usłyszę ich skargę i zapali się gniew mój i wygubię was mieczem i będą żony wasze wdowami, a dzieci wasze sierotami" (Wj 22, 21-23).

37 Zob. Jo 31, 16-23. 